\title{
細線温度センサの応答特性と応答補償*
}

\author{
田川正人*1, 加藤健 次*1, 太田安彦*2
}

\section{Response Compensation of Fine-Wire Temperature Sensors}

\author{
Masato TAGAWA*3, Kenji KATO and Yasuhiko OHTA \\ ${ }^{* 3}$ Department of Envirommental Technology and Urban Planning, Nagoya Institute of Technology, \\ (jokiso cho, Showa ku, Nagoya shi, Aichi, 4668555 Japan
}

\begin{abstract}
Theoretical analysis of the frequency response of a fine wire temperature sensor such as a thermocouple or a cold wire was performed, and the strict solution of the response was derived by treating rigorously a boundary condition of heat transport between a temperature sensing part and its adjoining support. The solution obtained is highly universal and can express the frequency response of both a fine wire thermocouple and a cold-wire with a single equation. The validity of the theoretical solution was examined experimentally, and a response-compensation technique widely applicable to fine wire temperature sensors was developed based on the theoretical results. In this technique, any special apparatus for calibrating the dynamic response is unnecessary. The present response compensation technique can make fluctuating temperature measurement by a $3.2 \mu$ $\mathrm{m}$ tungsten wire well comparable to that by a $0.63 \mu \mathrm{m}$ platinum-wire which is regarded as one of the fastest temperature sensors commercially available.
\end{abstract}

Key Words : Sensor, Flow Measurements, Turbulent Flow, Heat Transfer, Response Compensation

\section{1. 緒言}

乱流場の温度測定ではセンサとして細線 (抵抗線や 熱電対)が広く用いられている。しかし，測定すべき 温度変動の周波数が $10^{3} \mathrm{~Hz}$ に達する場合には, 温度 センサの応答特性が問題となることが多い。たとえ ば，燃焼のような高温乱流場の温度測定に用いられる 線径 $25 \sim 40 \mu \mathrm{m}$ の細線熱電対の遮断周波数は一般に $20 \mathrm{~Hz}$ 以下と低速である. 一方, 線径 $0.6 \sim 5 \mu \mathrm{m}$ の 抵抗線 (金属細線からなる抵抗温度センサ) の応答は 熱電対に比べてはるかに高速である。しかし，感温部 の長さ $l$ と楾径 $d$ の比が十分に大きくない場合 (通常, $\left.l / d<10^{3}\right)$ には，抵抗線の軸方向熱伝導とその支持端 (以下ではプロングと呼ぶ) の熱慣性が連成する結果と して, $1 \sim 100 \mathrm{~Hz}$ という低周波数域で利得が低下寸 るという意外な問題が生じる．したがって，流体の温 度変動を低周波数から高周波数にわたり高い精度で測 定するには, 細線の応答特性を正しく知って適切に応 答補償することが非常に重要である.

温度変動に対する細線の応答特性を調べた研究は 多い. 周波数応答の解析法として，抵抗線については Petit $ら^{(1)}$ の方法が, 球状温接点 (bead) がある細線熱

* 原稿受付 2004 年. 8 月 25 日。

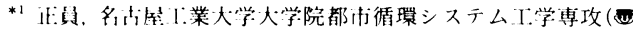
4668555 多古屋市昭和(御器所町)

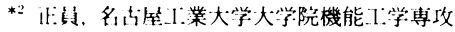

E mail : m.tagawa (a nitech.ac.jp
電対については Dupont $ら^{(2)}$ の方法が代表的なもので ある. ただし, 抵抗線の応答解析では, 感温部と隣接 する支持部との間の熱的境界条件が省略される(1) あるいは簡略に処理されている(3).この点について, Tsuji ら ${ }^{(4)}$ はそこでの境界条件を厳密に取り扱うこと に成功し, 抵抗線の周波数応答および抵抗線軸方向の 瞬時温度分布を実数の初等関数で表示できる理論解を 得ている.ただし，その解の導出には相当の計算が必 要であり, また, 解から周波数応答を求める数值計算 の手順も簡単ではない.

本研究では, Petit ら ${ }^{(1)}$ の方法を基礎として, Tsuji ら (4) と同様に感温部と隣接支持部の間の熱的境界条件を 厳密に扱うことにより, 細線温度センサの周波数応答 を表す理論解 (複素数の初等関数で表示される) を得 る、㛜密な境界条件を採用することにより, 従来は別 個の物理モデルに基づいて解析されていた細線熱電対 (温接点が球状の裸熱電対) と抵抗線の応答特性を単一 のモデルで表現できるようになる，すなわち，得られ る理論解は, 測定原理と形状が大きく異なる熱電対と 抵抗線の周波数応答を統一的に表示でき, 汎用性に優 れている. また, 理論解が伝達関数の形で表されるの で, 周波数応答の計算は簡明であり, 細線温度センサ の応答補償にも容易に適用できる. さらに, 著者らが 先に開発した周波数領域での時定数推定法 ${ }^{(5)}$ を利用す れば，センサの動特性を校正することなく，測定デー 
タから直接に伝達関数のパラメータ值を推定できる. 本研究の結果に基づいて熱電対の応答遅れや抵抗線の 低周波数域での利得低下を補償すれば, 乱流場におけ る変動温度測定の信頼性は大きく向上することが期待 できる。

\section{2. 記 号}

$$
\begin{aligned}
& a: \text { 温度伝導率 }\left[\mathrm{m}^{2} / \mathrm{s}\right] \\
& c: \text { 比熱 }[\mathrm{J} /(\mathrm{kg} \cdot \mathrm{K})] \\
& d: \text { 細線の直径 }[\mathrm{m}] \\
& f: \text { 周波数 }[\mathrm{Hz}] \\
& h: \text { 熱伝達率 }\left[\mathrm{W} /\left(\mathrm{m}^{2} \cdot \mathrm{K}\right)\right] \\
& j: \text { 虚数単位 }
\end{aligned}
$$$$
K \text { : 低周波数域での利得低下率 (抵抗線) }
$$$$
l: \text { 感温部またはビード (bead) の長さ }[\mathrm{m}]
$$$$
L: \text { プロング間の距離 }[\mathrm{m}]
$$

$T, \hat{T}:$ 温度 $[\mathrm{K}]$, そのフーリエ変換

$t:$ 時間 [s]

$x$ : 細線軸方向の座標 (図 1)

$\lambda:$ 熱伝導率 $[\mathrm{W} /(\mathrm{m} \cdot \mathrm{K})]$

$\nu:$ 動粘性係数 $\left[\mathrm{m}^{2} / \mathrm{s}\right]$

$\rho:$ 密度 $\left[\mathrm{kg} / \mathrm{m}^{3}\right]$

$\tau$ : 時定数 $[\mathrm{s}]\left(\equiv \omega_{\mathrm{c}}^{-1}, \omega_{\mathrm{c}}\right.$ : 遮断角周波数 $)$

$\Omega:$ 式 (8)

$\omega:$ 角周波数 $\left[\mathrm{s}^{-1}\right](\equiv 2 \pi f)$

添 字

1, 2, 3 : (抵抗線) 感温部, スタブ, プロング; (熱電対) ビード, 素線, プロング

$\mathrm{cw}, \mathrm{th}$ ：抵抗線, 熱電対

g : センサ周囲の流体

\section{3. 細線の周波数応答理論}

変動温度場に置かれた細線の周波数応答を理論解析 するにあたり, 解析対象である温度プローブの形状と 座標系を図 1 のように設定する。図1(a), (b) はそれぞ れ抵抗線と熱電対を用いた温度測定プローブを示す. 図1(a) の抵抗線プローブでは, 通常, タングステンや 白金の素線 (感温部) と支持端 (プロング, prong)の間 に銅や銀の支持部 (スタブ, stub) が介在することが多 い.これは，センサの素材として銅メッキされたタン グステン線や銀被覆された白金線 (Wollaston 線) を用 いるためである. 図1(b) の熱電対プローブでは, ビー ド (bead：異種金属の接合部)の形状を球ではなく円柱 と仮定している。その理由は, i) 現実のビード形状が 球というより円柱に近いことが多い; ii) 以下に示すよ

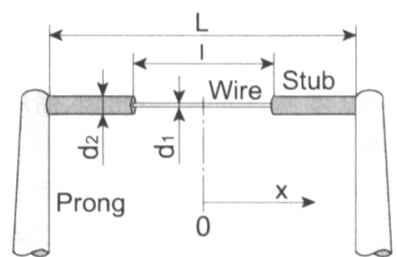

(a) Cold-wire

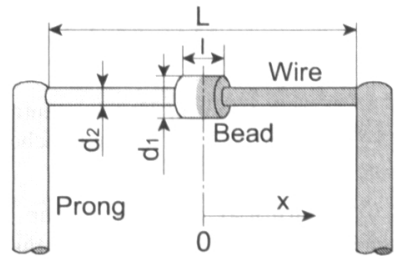

(b) Thermocouple

Fig. 1 Sensor configuration and coordinates

うに円柱とすることで抵抗線プローブと熱電対プロー ブを同じ物理モデルで表現できるからである。なお， 4.1 節で述べるように; 本理論はビードの形状が球で あっても図 1(b) の円柱の直径 $d_{1}$ と長さ $l$ を適切な值 に設定することにより適用可能である.

以下にその物理モデルを示す.まず，図1(a)の抵抗 線感温部とスタブ, 図 1(b) のビ一ドと熱電対素線の ジュール発熱および熱放射の影響を無視する。また， それらの線直径が小さいことから，断面内 (円柱の半 径方向) の温度分布は一様であると仮定する. 加えて, 熱電対については $2 つ の$ 異種金属の物性值の差異が十 分に小さい場合を対象とする，以上により，各プロー ブの熱伝導方程式と境界条件は次式で与えられる。

・抵抗線感温部またはビード $(0 \leq x \leq l / 2)$

$$
\frac{\partial T_{1}}{\partial t}=-\frac{1}{\tau_{1}}\left(T_{1}-T_{\mathrm{g}}\right)+a_{1} \frac{\partial^{2} T_{1}}{\partial x^{2}}
$$

・スタブまたは熱電対素線 $(l / 2 \leq x \leq L / 2)$

$$
\frac{\partial T_{2}}{\partial t}=-\frac{1}{\tau_{2}}\left(T_{2}-T_{\mathrm{g}}\right)+a_{2} \frac{\partial^{2} T_{2}}{\partial x^{2}}
$$

·境界条件

$$
\begin{aligned}
\text { i) } x=0: & \frac{\partial T_{1}}{\partial x}=0 \\
\text { ii) } x=l / 2: & T_{1}=T_{2} \\
\text { iii) } \quad x=l / 2: & \frac{\pi}{4} d_{1}^{2} \lambda_{1} \frac{\partial T_{1}}{\partial x}=\frac{\pi}{4} d_{2}^{2} \lambda_{2} \frac{\partial T_{2}}{\partial x} \\
\text { iv) } \quad x=L / 2: & T_{2}+\tau_{3} \frac{\partial T_{2}}{\partial t}=T_{\mathrm{g}}
\end{aligned}
$$

ここで, $a(=\lambda / \rho c)$ は温度伝導率であり, $T, \lambda, \rho, c$ は それぞれ温度, 熱伝導率, 密度, 比熱を表す。添字に 
ついては，1は抵抗線感温部またはビードを，2 はス タブまたは熱電対素線を, 3 はプロングを, $\mathrm{g}$ は周囲 流体を表す. また， $\tau$ は時定数 $\left(=1 / 2 \pi f_{\mathrm{c}}, f_{\mathrm{c}}\right.$ : 遮断周 波数)であり, 次式で定義される.

$$
\tau=\frac{\rho c d}{4 h}=\frac{\rho c d^{2}}{4 \mathrm{Nu} \lambda_{\mathrm{g}}}
$$

\section{ここで, Nu はヌセルト数である.}

式 (3) の境界条件 i) iv) では, i) 感温部の $x$ 方向の 温度分布が原点 $x=0$ について対称である; ii) 抵抗線 とスタブもしくはビードと素線の温度が接合点 $x=l / 2$ で一致する; iii) 接合面 $x=l / 2$ を通過する熱量が等 しい; iv) プロング先端の温度 (すなわち, $x=L / 2$ でのスタブの温度) が流体の変動温度 $T_{\mathrm{g}}$ に対して時 定数 $\tau_{3}$ の 1 次遅れ系で応答する; がそれぞれ定式化 されている. 条件 iii) が厳密な熱的境界条件 ${ }^{(4)}$ であ る. それまでの研究では, 接合点 $x= \pm l / 2$ において $T_{1}(t, l / 2)=T_{1}(t,-l / 2), T_{2}(t, l / 2)=T_{2}(t,-l / 2)$ とな る条件を導入して条件 i) と iii) を省略する ${ }^{(1)}$ か，ある いは条件 iii) の代わりとして $d_{1} \ll d_{2}$ の仮定の下に $\partial T_{2} / \partial x=0$ を与えて簡略化している( ${ }^{(3)}$. なお, 前者 の条件 ${ }^{(1)}$ を用いることは, 図 1(a)に示すように感温部 をはさんで分離しているスタブをプロング間で仮想的 に連続して存在するとして解析することに対応する. このような境界条件を用いれば解の導出は容易である が，その解は厳密ではない，条件iv)の仮定の妥当性 は, Paranthoen $\zeta^{(6)}$, Højstrup $ら^{(7)}$, Perry $ら^{(8)}$, 蒔田 $ら^{(9)}$ の各実験により確認されている.

以下では，著者らが先に報告したサーミスタの周 波数応答解析 ${ }^{(10)}$ と同様の手順で理論解析する. まず, $T_{1}(t, x), T_{2}(t, x), T_{\mathrm{g}}(t)$ を次式のようにフーリエ積分 で表現する.

$$
\left.\begin{array}{l}
T_{1}(t, x)=\int_{-\infty}^{\infty} \mathrm{e}^{j \omega t} \hat{T}_{1}(\omega, x) \mathrm{d} \omega \\
T_{2}(t, x)=\int_{-\infty}^{\infty} \mathrm{e}^{j \omega t} \hat{T}_{2}(\omega, x) \mathrm{d} \omega \\
T_{\mathrm{g}}(t)=\int_{-\infty}^{\infty} \mathrm{e}^{j \omega t} \hat{T}_{\mathrm{g}}(\omega) \mathrm{d} \omega
\end{array}\right\}
$$

式(5)から, 式 (1), (2) は次のように変換される.

$$
\left.\begin{array}{c}
\frac{\partial^{2}\left[\hat{T}_{1}(\omega, x)\right]}{\partial x^{2}}-\frac{1+j \omega \tau_{1}}{a_{1} \tau_{1}} \hat{T}_{1}(\omega, x) \\
=-\frac{\hat{T}_{\mathbf{g}}(\omega)}{a_{1} \tau_{1}} \\
\frac{\partial^{2}\left[\hat{T}_{2}(\omega, x)\right]}{\partial x^{2}}-\frac{1+j \omega \tau_{2}}{a_{2} \tau_{2}} \hat{T}_{2}(\omega, x) \\
=-\frac{\hat{T}_{\mathbf{g}}(\omega)}{a_{2} \tau_{2}}
\end{array}\right\}
$$

式 (6) は $x$ についての常微分方程式であり, その解は 次式で与えられる.

$$
\left.\begin{array}{c}
\hat{T}_{1}(\omega, x)=C_{1} \mathrm{e}^{+\Omega_{1} x}+C_{2} \mathrm{e}^{-\Omega_{1} x} \\
+\frac{\hat{T}_{\mathrm{g}}(\omega)}{a_{1} \tau_{1} \Omega_{1}^{2}} \\
\hat{T}_{2}(\omega, x)=C_{3} \mathrm{e}^{+\Omega_{2} x}+C_{4} \mathrm{e}^{-\Omega_{2} x} \\
+\frac{\hat{T}_{\mathrm{g}}(\omega)}{a_{2} \tau_{2} \Omega_{2}^{2}}
\end{array}\right\}
$$

ここで, $C_{1} \sim C_{4}$ は未定係数であり, $\Omega_{i}(i=1,2)$ は 次式で定義される.

$$
\begin{aligned}
\Omega_{i} \equiv & \sqrt{\frac{1+j \omega \tau_{i}}{a_{i} \tau_{i}}} \\
= & \frac{1}{\sqrt{2 a_{i} \tau_{i}}}\left(\sqrt{\sqrt{1+\omega^{2} \tau_{i}^{2}}+1}\right. \\
& \left.+j \sqrt{\sqrt{1+\omega^{2} \tau_{i}^{2}}-1}\right)
\end{aligned}
$$

同様に，境界条件 (3) の i) 〜 iv) をフーリエ積分で変 換し，それらを用いて式 (7) 中の係数 $C_{1} \sim C_{4}$ を決定 することで解を得る。

本解析の目的は抵抗線感温部あるいは熱電対ビード の周波数応答 $H(\omega)$ を求めることである. 感温部/ビー ドには $x$ 方向に温度分布があり, センサはその温度分 布の平均値を出力すると仮定する. この仮定の妥当性 については解析および実験により別途確認している. そこで, 次式のように $\hat{T}_{1}(\omega, x)$ を $x$ 方向に平均した值 $\hat{T}_{1 \mathrm{~m}}(\omega)$ で周波数応答を評価する.

$$
\hat{T}_{1 \mathrm{~m}}(\omega)=\frac{1}{l / 2} \int_{0}^{l / 2} \hat{T}_{1}(\omega, x) d x
$$

以上から，細線温度センサの感温部/ビードの周波数 応答 $H(\omega)\left(\equiv \hat{T}_{1 \mathrm{~m}}(\omega) / \hat{T}_{\mathrm{g}}(\omega)\right)$ が次のように求まる.

$$
\begin{gathered}
H(\omega)=\frac{1}{1+j \omega \tau_{1}}-\left[\frac{1}{1+j \omega \tau_{2}}-\frac{1}{1+j \omega \tau_{3}}\right. \\
\left.+\left(\frac{1}{1+j \omega \tau_{1}}-\frac{1}{1+j \omega \tau_{2}}\right) \cosh \left(\frac{\Omega_{2}(L-l)}{2}\right)\right] \\
\quad \times\left\{\frac { \Omega _ { 1 } l } { 2 } \left[\frac{\Omega_{1} \lambda_{1} d_{1}^{2}}{\Omega_{2} \lambda_{2} d_{2}^{2}} \sinh \left(\frac{\Omega_{2}(L-l)}{2}\right)\right.\right. \\
\left.\left.+\operatorname{coth}\left(\frac{\Omega_{1} l}{2}\right) \cosh \left(\frac{\Omega_{2}(L-l)}{2}\right)\right]\right\}^{-1}
\end{gathered}
$$

式 (10)により細線の周波数応答を計算するには, 時 定数 $\tau_{1}, \tau_{2}$ [式(4)参照] に含まれる細線の熱伝達率 $h$ が 必要になる. 本研究では, これを次の Collis \& Williams の式 ${ }^{(11)}$ で与える.

$$
\mathrm{Nu}\left(\frac{T_{\mathrm{f}}}{T_{\mathrm{g}}}\right)^{-0.17}=0.24+0.56 \mathrm{Re}^{0.45}
$$


Table 1 Physical properties of sensor materials

\begin{tabular}{lrcc}
\hline $\begin{array}{l}\text { Sensor } \\
\text { material }\end{array}$ & $\begin{array}{c}\rho \\
{\left[\frac{\mathrm{kg}}{\mathrm{m}^{3}}\right]}\end{array}$ & $\begin{array}{c}c \\
{\left[\frac{\mathrm{J}}{\mathrm{kg} \cdot \mathrm{K}}\right]}\end{array}$ & $\begin{array}{c}\lambda \\
{\left[\frac{\mathrm{W}}{\mathrm{m} \cdot \mathrm{K}}\right]}\end{array}$ \\
\hline Chromel $^{(12)}$ & 8670 & 444 & 17.4 \\
Constantan $^{(13)}$ & 8922 & 418 & 21.6 \\
Alumel $^{(12)}$ & 8750 & 461 & 48.3 \\
Platinum $^{(12)}$ & 21460 & 133 & 71.4 \\
Silver $^{(12)}$ & 10490 & 237 & 427 \\
Tungsten $^{(12)}$ & 19250 & 133 & 178 \\
Copper $^{(12)}$ & 8880 & 386 & 398 \\
\hline
\end{tabular}

ここで, ヌセルト数 $\mathrm{Nu}$, レイノルズ数 $\operatorname{Re}$ は，それ ぞれ $\mathrm{Nu}=h d / \lambda_{\mathrm{g}}, \mathrm{Re}=U d / \nu_{\mathrm{g}}(U:$ 流速, $\nu$ : 動 粘性係数) で定義される。また， $T_{\mathrm{f}}$ は膜温度であり， $T_{\mathrm{f}}=\left(T+T_{\mathrm{g}}\right) / 2(T$ : 細線表面の温度) で定義される.

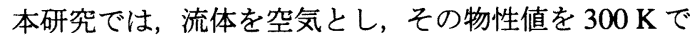
評価する. さらに，簡単のために $T \simeq T_{\mathrm{g}}$ と考えて， $T_{\mathrm{f}}=T_{\mathrm{g}}$ とおく. 表 1 に本解析の対象とした抵抗線感 温部，熱電対，スタブの材料の物性值を示す.

\section{4. 細線温度センサの周波数応答の解析}

この章では, 前章で導出した細線温度センサ周波数 応答の理論式 (10) の妥当性を実験的に検証する.

4.1 周波数応答式の検証最初に, 式 (10) を Tsuji $ら^{(4)}$ が得た周波数応答の理論解と比較する. Tsuji らの解は前述のように厳密な境界条件の下に導出され た解*であり，全てが実数の初等関数で表されている. 一方, 本研究の式 (10) は複素関数で表される厳密解で あり，表現が簡明なことと数値計算が容易な点 (計算 機言語では複素数をそのまま演算できる)に特長があ る. 両者が同一の結果を与えることを確認するために, Tsuji らと同じ条件で式 (10) を計算した. その結果, 両 者が数值演算の精度で一致することが確認された.

式 (10) は感温部と隣接する支持部との間の熱的境界 条件を厳密に満たすため, 熱電対のように感温部 (ビー ド) が支持部 (素線)に対して太くなる $\left(d_{1} / d_{2}>1\right)$ 場 合にも問題なく適用できる．本解析ではビードの形状 を図 1(b) のように円柱と仮定している，応答特性の 解析では，ビードの形状はその熱容量と熱伝達率を与 える際に関わるのみでそれを球とするか円柱とする かに本質的な差異はない，そこで，以下では，ビード 形状を高さと直径が等しい円柱 $\left(l=d_{1}\right)$ と仮定する. Dupont $ら^{(2)}$ の解析ではビード形状が直径 $d_{\mathrm{b}}$ の球と仮 定されているので, 式 (10) をDupont らの解析結果と

\footnotetext{
*Petit $ら^{(1)}$, Wroblewski-Eibeck ${ }^{(3)}$ の解は近似解ではあるが，抵 抗線感温部の直径 $d_{1}$ とスタブ直径 $d_{2}$ の比が $d_{1} / d_{2} \ll 1$ の場合 には, 蕨密解との差異はほとんどない, 通常の抵抗線プローブでは この条件が満たされている。
}

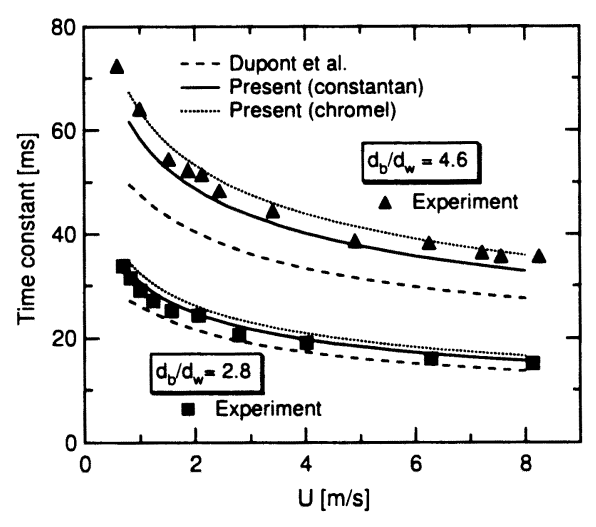

Fig. 2 Prediction of time-constant values

対比するには, ビードの熱容量を互いに合致させる必 要がある，そのためには，ビード部の円柱の体積が球 の体積と等しくなるように円柱直径 $d_{1}$ を与えればよ W†.

Dupont $ら^{(2)}$ は, $d_{\mathrm{w}}=25 \mu \mathrm{m}\left(d_{\mathrm{w}}\right.$ : 熱電対素線径) の $\mathrm{E}$ 型熱電対 (クロメル: コンスタンタン) を解析対象と し, 直径比 $d_{\mathrm{b}} / d_{\mathrm{w}}=2.8,4.6$ (ただし, $L / d_{2}>200$ )の 球形ビードをもつ場合について周波数応答の理論解を 導出し, それから得られた時定数を実験値と比較して いる. そこで, 本研究では, $d_{1} / d_{2}=2.8 \times(2 / 3)^{1 / 3}$, $4.6 \times(2 / 3)^{1 / 3}$ として, 式(10) から時定数 $\tau_{1}$ を求めた. なお, 時定数 $\tau$ は, 周波数応答の利得が $-3.0 \mathrm{~dB}$ とな る遮断周波数 $f_{\mathrm{c}}$ から $\tau=1 /\left(2 \pi f_{\mathrm{c}}\right)$ として求まる. 熱 電対ではビードが感温部として働くことから，ビード の物性値を表 1 によりクロメルあるいはコンスタンタ ンで与えた。 このようにして得られた時定数の予測結 果を図 2 に示す. 図 2 から, 本理論式 (10) による時定 数の予測值は Dupont らのそれに比べてより実験值に 近い. 特にビードの直径が大きい $d_{\mathrm{b}} / d_{\mathrm{w}}=4.6$ の場合 に予測精度がかなり改善されている。この結果から， 本理論によってビードのある細線熱電対の時定数を十 分な精度で予測できることがわかる。

以上の検証により, 式 (10) は, 抵抗線と熱電対とい う測定原理, 形状, 応答特性が大きく異なる 2 種類の 細線温度センサの周波数応答を統一的に表現できる普 遍性の高い理論式であることが示された。

4.2 細線熟至対の周波数応答 ここでは, 細線 熱電対の応答特性を支配する要因を明らかにする. 熱 電対として, 線径 $d_{2}=25 \mu \mathrm{m}$ の $\mathrm{K}$ 型熱電対 (クロメ ルーアルメル) を想定し, 式 (10)より流速 $4 \mathrm{~m} / \mathrm{s}$ にお ける周波数応答を種々の条件下で解析した. その結果

†式 (10)の $d_{1}$ を $d_{1}=(2 / 3)^{1 / 3} d_{\mathrm{b}}$ で置換すれば，Dupont $5^{(2)}$ の解析に相当する計算条件となる。 


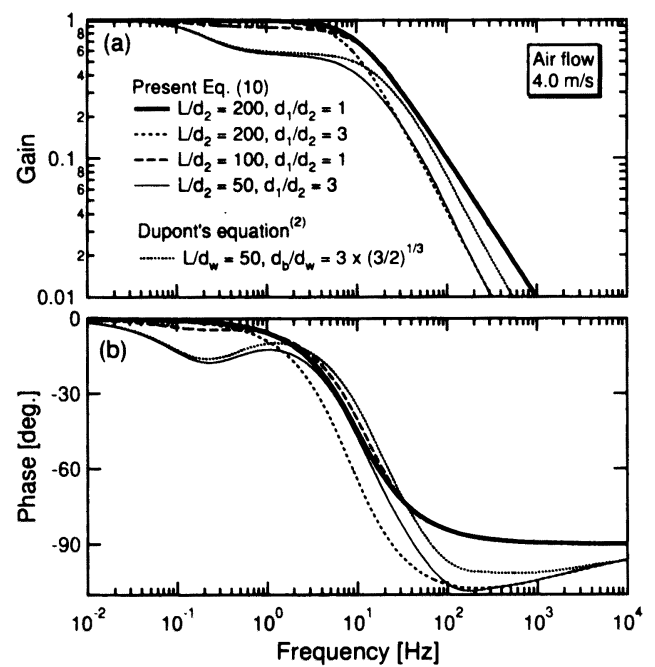

Fig. 3 Frequency response of thermocouples

をボード線図 (利得と位相) として図 3 に示す.ここ で，熱電対素線の物性值にはアルメルまたはクロメル のそれを与えたが, $L / d_{2} \geqq 100$ についてはほとんど 差異が見られなかった. ただし， $L / d_{2}=50$ について は，素線軸方向の熱伝導の影響がより顕著に現れるア ルメルの場合のみを図 3 に示している.

図 3 より，線長が十分に長く，ビードの直径が素線 径と等しい熱電対 $\left(L / d_{2}=200, d_{1} / d_{2}=1\right)$ では, 温 度変動の周波数が高くなると利得が $-20 \mathrm{~dB} / \mathrm{dec}$ で減 衰し，位相は $-\pi / 2$ に漸近する，すなわち，一次遅 れ系で态答することがわかる．ビードが大きくなる $\left(L / d_{2}=200, d_{1} / d_{2}=3\right)$ と, 一次遅れ系よりも利得 の低下が若干大きくなり，位相も $-\pi / 2$ を一旦下回っ たのち $-\pi / 2$ に漸近する.このことから，熱電対の 応答を一次遅れ系と仮定して応答補償する場合には, ビードがあまり大きくないことが前提となる．一方， 線長が短くなる $\left(L / d_{2}=100, d_{1} / d_{2}=1\right)$ と，低周 波数域での利得が 0.9 に低下する。，一般に，細線熱電 対を用いる場合は $L / d_{2}>250$ を満たすことが必要 (14)とされており，本解析結果もそれを裏づけている. さらに，線長が非常に短く，ビードの大きい熱電対 $\left(L / d_{2}=50, d_{1} / d_{2}=3\right)$ では，プロングの熱慣性に起 因して低周波数域で利得が大きく低下し, 高周波数域 では $L / d_{2}=200, d_{1} / d_{2}=3$ の応答に漸近する. 対応 する条件下で Dupont $ら^{(2)}$ の式を計算したところ，低 周波数域では式(10) と同じ挙動を示すものの, 高周波 数域では彼らの式の方が利得が低下しはじめる周波数 を高く予測する.このことは，図 2 において彼らの式 が式 (10) と比べて時定数を小さく予測することに帰

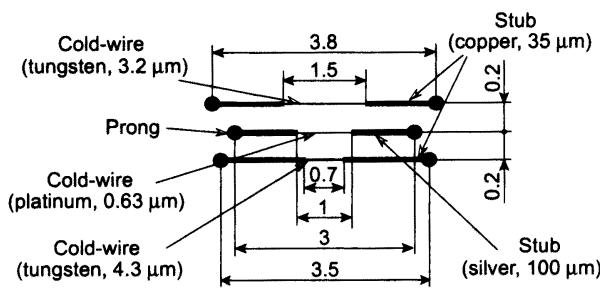

(a) Probe $\mathrm{A}$

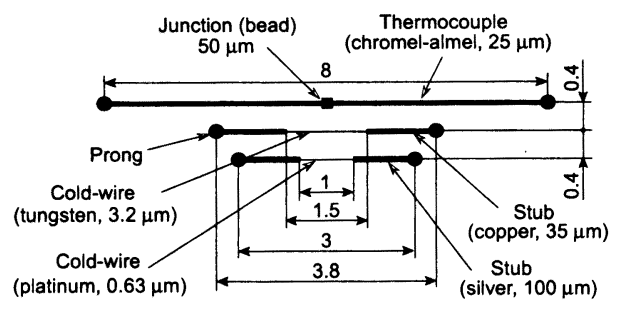

(b) Probe $\mathrm{B}$

Fig. 4 Details of temperature probes

結する.

4.3 種々の細線温度センサの周波数応答 ここ では, 代表的な細線温度センサをとりあげてその周波 数応答特性の詳細を明らかにする.これにより, 細線 温度センサの応答補償に必要な知見を得る。

解析対象とした細線温度センサの形状を図 4 に示す. 図 4(a), (b) の各プローブは変動温度計測に用いられる 代表的なセンサで構成されている. 熱電対には素線径 $25 \mu \mathrm{m}$ の $\mathrm{K}$ 型熱電対を, 抵抗線には線径 $3.2 \mu \mathrm{m}$ お よび $4.3 \mu \mathrm{m}$ のタングステン線きを, 基準センサとして は非常に高速な線径 $0.63 \mu \mathrm{m}$ の極細白金線 (Wollaston 線) をそれぞれ採用し，それらの周波数応答を式 (10) で解析した. 流速 $4 \mathrm{~m} / \mathrm{s}$ の空気中での周波数応答を図 5 に示す. この解析では式 (10) 中のプロング時定数 $\tau_{3}$ を前述のように $1 \mathrm{~s}$ に設定した ${ }^{(1)(3)(7)(8)}$ (本実験におい てもこの值の妥当性を別途確認している).

図 5 から, 図 4(b) の熱電対 $\left(L / d_{2}=320, d_{2} / d_{1}=2\right)$ は遮断周波数 $10 \mathrm{~Hz}$ 程度の 1 次遅れ系で応答すると見 てよい.一方, $3.2 \mu \mathrm{m}$ のタングステン線は熱電対に 比べてはるかに高速であるが, 一方で低周波数域で の利得が 0.84 に低下することが見てとれる．この低 下は抵抗線およびスタブの軸方向熱伝導とプロング の熱慣性が連成する結果として生じる(4)(6). 図 4(a), (b) に示す $3.2 \mu \mathrm{m}$ 抵抗線の感温部の長さと直径の比は

‡これらのタングステン線は線径 $3.1 \mu \mathrm{m}$ および $5 \mu \mathrm{m}$ として市 販されているものであるが，X 線マイクロアナライザー (影微鏡) で線径を実測したところ，それぞれ $3.2 \mu \mathrm{m}, 4.3 \mu \mathrm{m}$ であった. な お, $0.63 \mu \mathrm{m}$ の白金線については応答補供量が非常に小さいことか ら実測していない。 


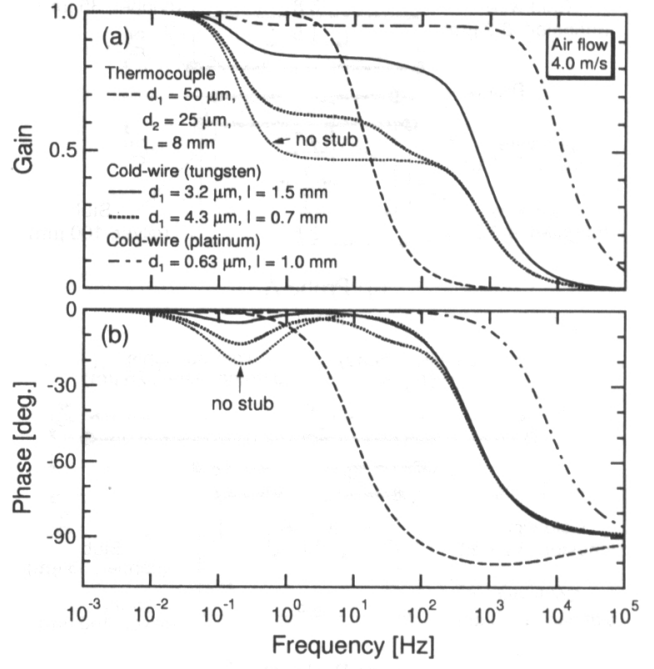

Fig. 5 Frequency response of fine-wire sensors

$l / d_{1}=469$ である.このように感温部が比較的短い $l / d_{1}=200 \sim 400$ の抵抗線は実際によく用いられる が, 低周波数域での利得の低下に十分な注意が必要で ある. 図 4(a) の $4.3 \mu \mathrm{m}$ タングステン線 $\left(l / d_{1}=163\right)$ の場合には, $1 \sim 10 \mathrm{~Hz}$ での利得が 0.63 にまで低下し ている. また, $3.2 \mu \mathrm{m}$ 抵抗線と比べてスタブの効果が 顕在化して, $10 \sim 100 \mathrm{~Hz}$ あたりでさらに利得が低下 する. $4.3 \mu \mathrm{m}$ 抵抗線について, 感温部 (細線) をスタ ブを設けずにプロングに直接スポット溶接すると, 図 5(a)に示すように利得はさらに低下するが応答特性は 素直になる ${ }^{(9)}$. 一方, $0.63 \mu \mathrm{m}$ 白金線 $\left(l / d_{1} \simeq 1500\right)$ の 場合には, 低周波数域での利得低下は小さく, 高周波 数域での応答特性も非常に優れている. しかし, 極細 白金線は非常に脆弱であるために, 実用上の制約が大 きく，適用範囲は極めて限定される.

4.4 理論解析に基づく細線温度センサの応答補償 前節の解析結果を踏まえて, ここでは $0.63 \mu \mathrm{m}$ 白金線 を基準センサとして熱電対および抵抗線 (タングステ ン線) の応答特性を実験的に検証する. また, 図 5 に 示す応答特性のタングステン線を用いて, その出力を 応答補償することにより $0.63 \mu \mathrm{m}$ 白金線と同等の測定 結果 (温度変動波形) を再現する方法を提案する。

最初に, 理論解である式 (10) に基づく応答補償法を 提示し検証する. 応答補償は, 抵抗線出力を高速フー リエ変換し, その結果に式 (10) の逆数 $1 / H(\omega)$ をかけ た後, 高速逆フーリエ変換することで実現される ${ }^{(15)}$.

検証実験では, 図 6 に示すように鈶直上向きに設置 された風洞の出口付近に円柱電気ヒータを取りつけ, その後方に形成される変動温度場を利用した. 使用し

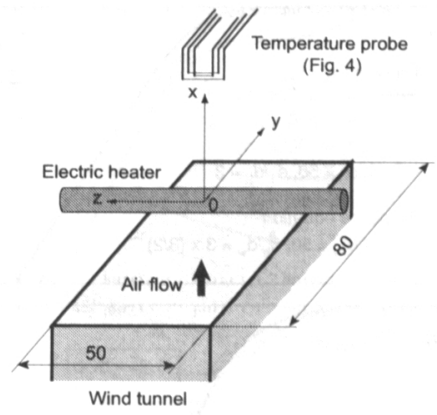

Fig. 6 Experimental apparatus

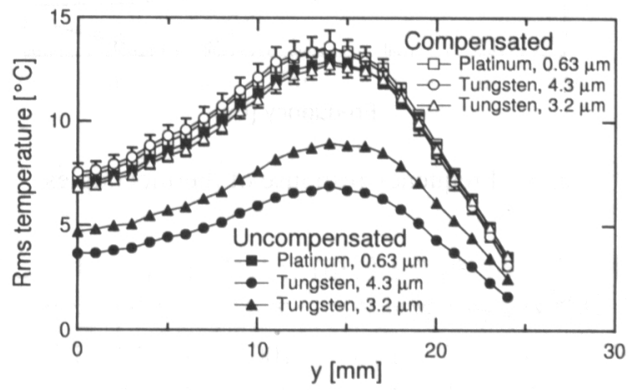

Fig. 7 Rms temperature

た温度プローブは図 4(a) に示すものであり, 線径 3.2 $\mu \mathrm{m}, 4.3 \mu \mathrm{m}$ のタングステン線と $0.63 \mu \mathrm{m}$ 白金線が, 互 いに干渉しない範囲で可能な限り接近するようにそれ ぞれ $0.2 \mathrm{~mm}$ の間隔で配置されている. なお，抵抗線 の駆動電流はその自己発熱が $0.07{ }^{\circ} \mathrm{C}$ 以下になるよう に設定されている. 測定対象は $z=0 \mathrm{~mm}$ の面におけ る $x=60 \mathrm{~mm}, y \geqq 0 \mathrm{~mm}$ の領域である. 風洞出口で の $x$ 方向の平均流速は $4 \mathrm{~m} / \mathrm{s}$ である. 温度センサの出 力は 12 ビット $\mathrm{A} / \mathrm{D}$ 変換器 (3 チャンネル) で同時に㕍 散化される。.サンプリング周波数は $5 \mathrm{kHz}$ ，データ数 は各センサあたり $2^{15}(=32768)$ である.

測定された温度変動の実効值 (rms 值) を応答補償前 と補償後を対比して図 7 に示す。 なお, 応答補償後の データについては FIR 低域通過フィルタにより $2 \mathrm{kHz}$ 以上の高周波数成分の寄与が低減されている. 図 7 か らわかるように，応答補償によって 3 つのセンサの測 定值はほぼ合致し，応答補償が有効に機能することが 確認できる. なお, $3.2 \mu \mathrm{m}$ タングステン線の応答補償 後の $\mathrm{rms}$ 值が若干小さいが, これには線長が $1.5 \mathrm{~mm}$ と長いために温度変動が感温部で空間的に平均化され $ろ^{(16)}$ 現象が影響していると考えられる.

次に, $\mathrm{rms}$ 值が最大となる $y=14 \mathrm{~mm}$ の位置で測定 された応答補償前と補償後の温度波形を図 8 に示寸. 図 8(a) から, 応答補償前のタングステン線の出力には 

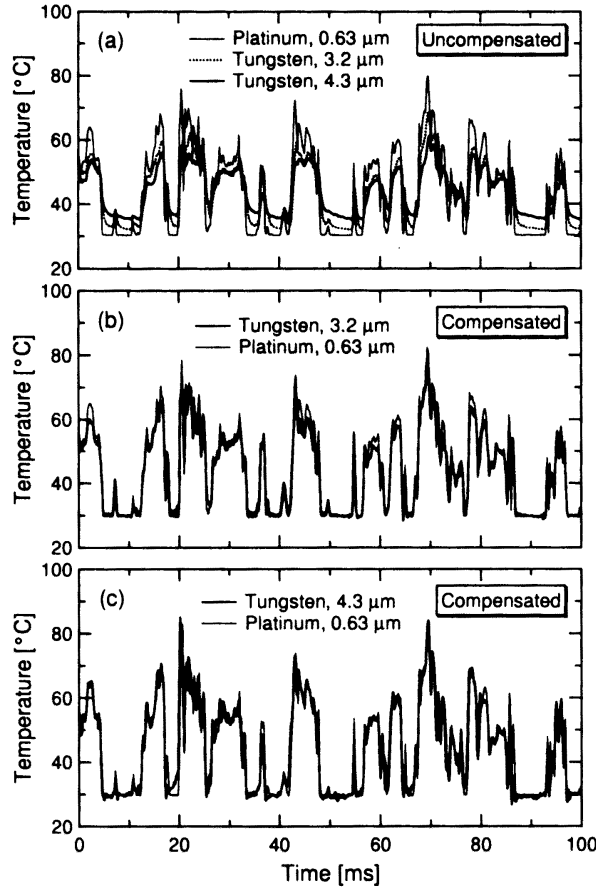

Fig. 8 Response compensation of cold-wire [Eq. (10)]

低周波数域での利得低下に起因する減衰が見られる. 特に $4.3 \mu \mathrm{m}$ のタングステン線ではそれが顕著に現れ ている，一方，図 8(b), (c) の応答補償後の波形を見る と, 低周波数から高周波数にわたる広い範囲の変動成 分が再生される結果, $3.2 \mu \mathrm{m}, 4.3 \mu \mathrm{m}$ タングステン線 の波形はともに $0.63 \mu \mathrm{m}$ 白金線の波形とよく一致して いる.この一致の程度は, センサの位置と測定体積が 互いに異なることを考慮すれば，十分に満足できるも のである.

4.5 応答特性の同定とそれに基つく応答補偵 4.4 節では，式（10）に基づく応答補償法を示した，本 節では，著者らが先に開発した二線式熱電対変動温度 測定法 ${ }^{(15)(17)}$ および周波数領域での時定数推定法 ${ }^{(5)}$ を 利用して, 抵抗線の出力 (測定データ) から伝達関数の パラメータ值を決定し応答補償する方法を提案する. 4.2 節で述べたように，抵抗線の応答補償では低周波 数域での応答特性を改善することが本質的に重要であ る. そこで, 高周波数域での応答特性を規定する時定 数 $\tau_{\mathrm{cw}}\left(\tau_{1}\right.$ に対応) については式 (10) の計算結果によ り与えて, 低周波数域の特性を改善する方法を以下に 提案する. この方法の利点は, 抵抗線感温部の線径を 除く他の幾何学的パラメータの值を与える必要がない ことである.

一般に, 温度センサの出力 $T(t)[t:$ 時間 $]$ のフーリ
工変換 $\hat{T}(f)[f$ : 周波数 $]$ は $\hat{T}(f)=R(f)+j I(f)$ で表 される. 以下では, ( ) はフーリェ変換を, $R(f), I(f)$ はフーリエ変換の実部と虚部を表す。これから, 熱電 対と抵抗線で測定された温度 $T_{\mathrm{th}}(t), T_{\mathrm{cw}}(t)$ のフーリ 工変換 $\hat{T}_{\mathrm{th}}(f), \hat{T}_{\mathrm{cw}}(f)$ はそれぞれ次式で表される.

$$
\left.\begin{array}{l}
\hat{T}_{\mathrm{th}}(f)=R_{1}(f)+j I_{1}(f) \\
\hat{T}_{\mathrm{cw}}(f)=R_{2}(f)+j I_{2}(f)
\end{array}\right\}
$$

4.2 節の解析結果に基づいて, 熱電対は時定数 $\tau_{\mathrm{th}}$ の 1 次遅れ系で応答すると仮定する。一方, 抵抗線の忘 答特性は, 極めて低い周波数の温度変動 (ゆらぎ) の寄 与が無視できる通常の乱流場では，低周波数域では利 得が $1 / K_{\mathrm{cw}}$ に低下し, 高周波数域では時定数 $\tau_{\mathrm{cw}}$ の 1 次系で応答すると見なせる. したがって, これらの 応答式は次式の伝達関数で近似される.

$$
\left.\begin{array}{l}
H_{\mathrm{th}}(\omega)=\left(1+j \omega \tau_{\mathrm{th}}\right)^{-1} \\
H_{\mathrm{cw}}(\omega)=\left(K_{\mathrm{cw}}+j \omega \tau_{\mathrm{cw}}\right)^{-1}
\end{array}\right\}
$$

式 (13) から, 熱電対と抵抗線の出力 $T_{\mathrm{th}}, T_{\mathrm{cw}}$ を周波 数領域で応答補償するとき, 応答補償後の温度の周波 数成分は式 (12), (13) から,

$$
\left.\begin{array}{l}
\hat{T}_{\mathrm{gth}}=\left(1+j \omega \tau_{\mathrm{th}}\right)\left(R_{1}+j I_{1}\right) \\
\hat{T}_{\mathrm{gcw}}=\left(K_{\mathrm{cw}}+j \omega \tau_{\mathrm{cw}}\right)\left(R_{2}+j I_{2}\right)
\end{array}\right\}
$$

となる. 近接するセンサについては $T_{\mathrm{gth}} \simeq T_{\mathrm{gcw}}$ が成 立する. そこで, 二線式熱電対法 ${ }^{(5)(15)(17)}$ の考え方を式 (14) に適用すれば $\tau_{\mathrm{th}}, K_{\mathrm{cw}}$ の值を推定できる. 図 5 を 参照して設定される周波数区間 (本実験では, $0.1 \sim 10$ $\mathrm{Hz})$ での平均を〈〉で表すとき, $\left\langle\left|\hat{T}_{\mathrm{gth}}-\hat{T}_{\mathrm{gcw}}\right|^{2}\right\rangle$ を最 小化する $\tau_{\mathrm{th}}, K_{\mathrm{cw}}$ を求めればよい，結果は次式で表 される.

$$
\left.\begin{array}{c}
\tau_{\mathrm{th}}=\frac{P_{12} C_{22} \tau_{\mathrm{cw}}+P_{13} C_{12}}{P_{11} C_{22}-\left(P_{13}\right)^{2}} \\
K_{\mathrm{cw}}=\frac{P_{12} P_{13} \tau_{\mathrm{cw}}+P_{11} C_{12}}{P_{11} C_{22}-\left(P_{13}\right)^{2}}
\end{array}\right\}
$$

ここで, $P_{11}, P_{22}, P_{12}, P_{13}, C_{12}, C_{22}$ は次式で与えら れる.

$$
\left.\begin{array}{l}
P_{11}=\left\langle\left(R_{1}^{2}+I_{1}^{2}\right) \omega^{2}\right\rangle \\
P_{22}=\left\langle\left(R_{2}^{2}+I_{2}^{2}\right) \omega^{2}\right\rangle \\
P_{12}=\left\langle\left(R_{1} R_{2}+I_{1} I_{2}\right) \omega^{2}\right\rangle \\
P_{13}=\left\langle\left(R_{1} I_{2}-R_{2} I_{1}\right) \omega\right\rangle \\
C_{12}=\left\langle R_{1} R_{2}+I_{1} I_{2}\right\rangle, C_{22}=\left\langle R_{2}^{2}+I_{2}^{2}\right\rangle
\end{array}\right\}
$$

検証実験では 4.4 節と同様に図 6 に示す変動温度場 中で図 4(b) のプローブを $y$ 方向にゆっくりと摇動させ て温度データを取得した. 温度プローブには, $25 \mu \mathrm{m}$ 


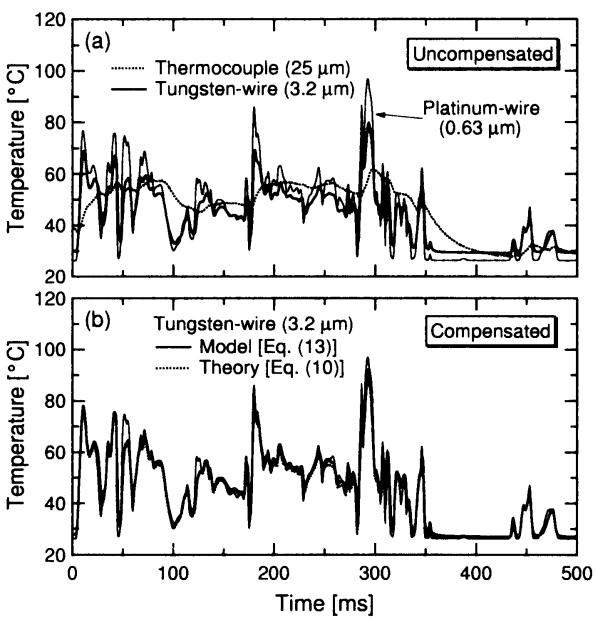

Fig. 9 Response compensation of cold-wire [Eq.(13)]

の $\mathrm{K}$ 型熱電対, $3.2 \mu \mathrm{m}$ タングステン線, $0.63 \mu \mathrm{m}$ 白金 線が図 4(b) のように配置されている．なお，本実験で は低周波数の温度変動波形に注目するため風洞出口で の $x$ 方向平均流速を $1.5 \mathrm{~m} / \mathrm{s}$ に設定した.

図 9 にその結果を示す. 図 9(a) の応答補償前の温 度データから, 式 (15)により熱電対の時定数 $\tau_{\mathrm{th}}$ と抵 抗線の利得低下率 $K_{\mathrm{cw}}$ を計算したところ， $\tau_{\mathrm{th}}=24.3$ $\mathrm{ms}, K_{\mathrm{cw}}=1.28$ を得た。 $K_{\mathrm{cw}}$ のこの值は低周波数域 での利得低下率 (すなわち $1 / K_{\mathrm{cw}}$ ) が 0.78 であること を示しており，流速 $1.5 \mathrm{~m} / \mathrm{s}$ の場合の式 (10)による解 析結果 0.81 に近い. 同様に $\tau_{\mathrm{th}}=24.3 \mathrm{~ms}$ という推定 值も理論値の $24.1 \mathrm{~ms}$ とほぼ一致する.そこで,これ らの推定值に基づいて図 9(a) の測定データを応答補償 する．応答補償は式 (14) を逆フーリエ変換することで 実現される。図 9(b)には式 (10) または式 (13)に基づ いて応答補償された抵抗線の温度変動波形を示す。た だし, 熱電対の応答補償後の波形は見やすくするため に省かれている.タングステン線の応答補償後の波形 からわかるように, 厳密解である式 (10) とモデル化さ れた式(13)のどちらによっても低周波数域から高周波 数域にわたる変動成分が再生されて, 応答補償の必要 がない $0.63 \mu \mathrm{m}$ 白金線の温度波形とほぼ合致する．以 上の結果から，式 (10) あるいは式 (13)に基づいて応 答補償すれば, $3.2 \mu \mathrm{m}$ タングステン線によっても 0.63 $\mu \mathrm{m}$ 白金線と同程度の高い精度で変動温度を測定でき ることが示された。

\section{5. 結言}

熱電対や抵抗線に代表される細線温度センサの周波 数応答の理論解を, 感温部と隣接支持部との間の熱移
動を厳密に反映する境界条件の下で導出した，本理論 解には, 熱電対と抵抗線という測定原理, 形状, 応答 特性が大きく異なる温度センサの周波数応答を単一の 式で表現できる利点がある. 次いで, 本理論解の妥当 性および汎用性を実験的に検証するとともに，それに 基づく細線温度センサの忘答補償法を開発した。これ により,これまで困難と考えられてきた抵抗線の周波 数応答特性 (低周波数域での利得低下率) の同定および その応答補償が可能となった。この同定には特別な校 正装置は必要ない。 以上の成果に基づいて, 線径 3.2 $\mu \mathrm{m}$ のタングステン線を応答補償することによって, 非 常に高速な $0.63 \mu \mathrm{m}$ 白金線を用いた場合に匹敵する信 頼性の高い変動温度測定を実現できた。

\section{謝辞}

本研究の一部は科学研究費補助金 [基盤研究, No. 17106003, 17560183]によった.

\section{文献}

(1) Petit, C., Paranthoen, P. and Lecordier, J. C., Lett. Heat Mass Transf., 8 (1981), 281-291.

(2) Dupont, A., Paranthoen, P., Lecordier, J. C. and Gajan, P., J. Phys. E: Sci. Instrum., 17 (1984), 808-812.

(3) Wroblewski, D. E. and Eibeck, P. A., Exp. Therm. Fluid Sci., 4 (1991), 452-463.

(4) Tsuji, T., Nagano, Y. and Tagawa, M., Exp. Fluids, 13 (1992), 171-178.

(5) Tagawa, M., Kato, K. and Ohta, Y., Review Sci. Instrum., 74 (2003), 3171-3174.

(6) Paranthoen, P., Petit, C. and Lecordier, J. C., J. Fluid Mech., 124 (1982), 457-473.

(7) Højstrup, J., Rasmussen, K. and Larsen, S. E., DISA Information, No. 20 (1976).

(8) Perry, A. E., Smith, A. J. and Chong M. S., J. Fluid Mech., 90 (1979), 415-431.

（9）蒔田秀治・澤田耕二・森重樹，機論，58-554，B (1992), 154-161.

(10) Tagawa, M., Kato, K. and Ohta, Y., Review Sci. Instrum., 74 (2003), 1350-1358.

(11) Collis, D. C. and Williams, M. J., J. Fluid Mech., 6 (1959), 357-384.

（12）熱物性ハンドブック編集委員会, 熱物性ハンドブック, (1990), pp. 22-27, 養買堂.

(13) Donald, R. P. and Leighton, E. S., Heat Transfer, (1977), p. 306, McGraw-Hill.

(14) Bradley, D. and Matthews, K. J., J. Mech. Eng. Sci., 10 (1968), 299-305.

(15) Tagawa, M., Shimoji, T. and Ohta, Y., Review Sci. Instrum., 69 (1998), 3370-3378.

(16) Wyngaard, J. C., Phys. Fluids, 14 (1971), 2052-2054.

(17) Tagawa, M. and Ohta, Y., Combust. Flame, 109 (1997), 549-560. 